Stanisław Tkaczyk

Wyższa Szkoła Logistyki w Poznaniu

E-mail: stanislaw.tkaczyk@wsl.com.pl

\title{
QUALITY ENGINEERING AND ITS APPLICATIONS IN LOGISTICS
}

\begin{abstract}
Background: The chapter presents the scope and trends in quality engineering in the aspect of this discipline, which has an extensive set of analytical and organizational methods, helpful in obtaining and maintaining economically justified quality of products and services. General economic quality engineering tasks derived from the basics of qualitology in the science of modern economy were discussed. Selected quality engineering applications for solving real problems in the broadly understood logistics in relation to transport, production management and machine technology - based on modern quantitative methods are presented. It was pointed out that such activities lead to actual assessment and improvement of implemented processes in the presented logistics areas.
\end{abstract}

Methods: The work refers to quality engineering methods used in logistics in the broad sense. The basics and application of modern qualitative methods based mainly on engineering statistics and expert methods are presented.

Results: The examples of quality engineering applications in logistics presented in the chapter have shown that qualitative methods lead to the assessment, elimination of incompatibilities and improvement of processes implemented in logistics.

Conclusions: The use of quality engineering methods in modern logistics is one of the important elements improving the processes implemented, and thus bringing the interested organizations closer to the organization conventionally referred to as the perfect organization.

Keywords: logistics, quality engineering, qualitative methods, selected examples.

\section{INTRODUCTION}

In the current turbulent environment, logistics is a dynamically developing area of science and business, dealing with optimal flows of people, goods, information between individual entities [Brzeziński 2015]. 
Proper fulfillment of these logistic functions requires their validation at each stage, as well as full quality assurance, which should lead to the fulfillment of services agreed with the recipient. [Łunarski 2009; Blaik 2011]. Therefore, among many other fields of science, the achievements of applied qualitology, referred to as quality engineering, are increasingly used in this area. According to the creator of this discipline - prof. R. Kolman - quality engineering is defined as a practical discipline used in a wide variety of applications - for shaping the most advantageous economically justified quality in economic systems [Kolman 2009].

The implementation of the above assumptions has a positive impact, among others on the state of customer satisfaction with the service received, and also reduces the risk of business management - also in the economic aspect of the entire service chain, e.g. work. [Noga, Noga, 2019]. The quoted reflections were the basis for the development of this chapter.

The chapter briefly presents the scope and trends in quality engineering, as well as selected quality engineering applications for solving real problems in the broadly understood logistics - in relation to transport, production management and machine technology.

\section{TASKS AND THE STATE OF QUALITY ENGINEERING}

The creator of quality engineering presented the most important, in his opinion, general economic tasks of this discipline. In simplified terms they include [Kolman 2009]:

- Analysis of practical social needs regarding quality,

- Hierarchy of previously separated needs from the point of view of general social interests,

- Determining optimal methods of pro-quality activities for specific groups of processes and products,

- Development of methodology and equipment for automatic quality control and others.

- The presented list of logistics processes mainly falls in the last two points of quality engineering tasks.

Going further - the development of quality engineering methods should aim primarily at improving, obtaining and using reliable information about the state of quality in the analyzed processes and their products (services). It is assumed that these activities should aim primarily at [Tkaczyk 2000]:

- Development of computer programs for the most accurate methods of quantifying the level of quality, suitable for practical applications, including in logistics, 
- Developing principles for the rational use of quality methods and standards in management systems, including logistics,

- Developing analytical methods of diagnosis in management systems - including logistics processes - with the use of quality engineering methods,

- Creating analytical methods for detailed examination of losses caused by incomplete use of existing opportunities, maintaining the level of quality of implemented processes with the participation of quality costs and creating unused reserves in implemented logistics processes, and

- Periodic analysis of the effectiveness of actions taken - including in logistics operations, to make necessary adjustments and more.

In addition to the important cognitive aspects, these activities also have, among others great importance and application in logistics. When it comes to applications of quality engineering methods, they most often refer to management and quality sciences. Thus, they fall within the area of broadly understood logistics.

In the group of quality engineering research methods that are of great importance in logistics - there are methods applied from various fields of science, including research, evaluation and quality improvement, are referred to as qualitative methods. They mainly include expert, organizational and statistical techniques - eg works [Dudek 2002; Tkaczyk 2010; Tkaczyk 2018]. They are mainly derived from the W.E. Deming PDCA (Plan-DoCheck-Act) cycle and its development - the DMAIC (Define -Measure-Improve-Control) cycle, as well as the philosophy and method of TOM, Kaizen and Hoshin Kanri. - Figure 1.

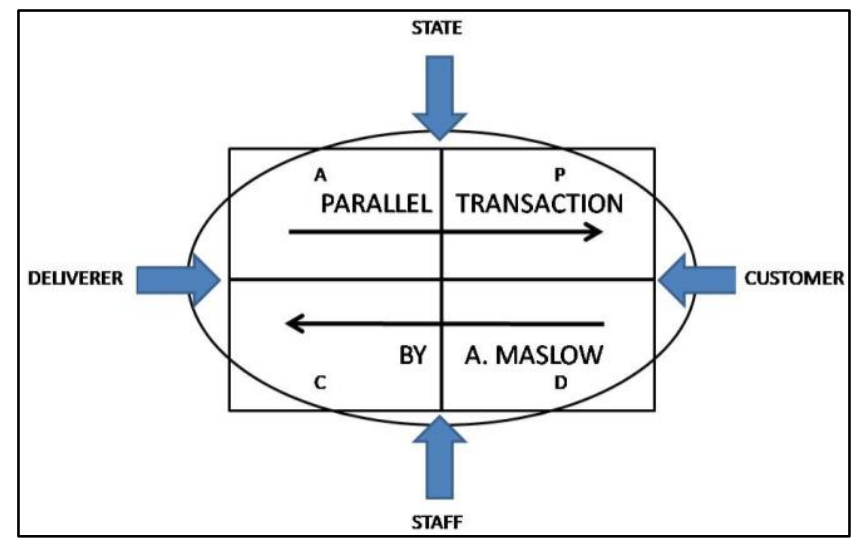

Fig.1 Deming wheel quadrature. Source: [Tkaczyk 2000]

They include so-called old and new quality tools as well as methods of engineering statistics used in machine technology, eg works - [Dudek 2002; Tkaczyk 2010; Sałaciński 2016] - Figure. 2. 


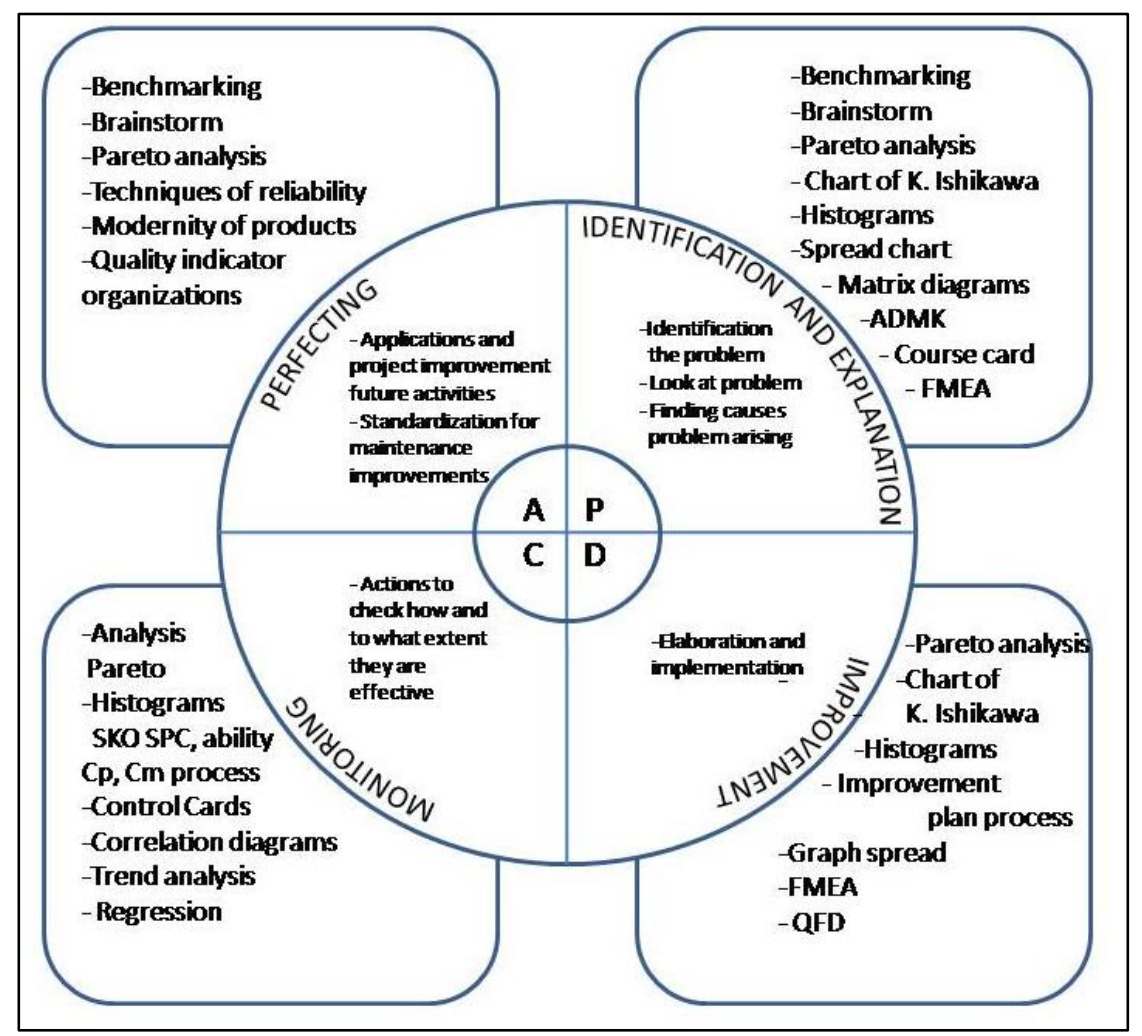

Fig. 2. The PDCA circle and selected qualitative methods. Source: [Dudek 2002].

As you know - systems, objects and logistic elements as links can create different types of configurations. The basic systems are logistic chains and networks, which are also systems [Brzeziński 2015]. The listed objects and elements of the logistics system also require testing, evaluation and improvement, briefly mentioned methods of quality engineering.

In addition, there are more and more frequent cases of creating models in the area of management and quality - with the possibility of application also in logistics. Similarly to the application of planning holarchy [Kowalska-Napora 2007].

A further example is the possibility to include issues in the field of quality economics (quality costs) in terms of logistics services and the risk factor [Szczepańska 2009; Noga and Noga 2019]. The above, in conjunction with the developed innovation on the economy scale, through incremental and radical innovations, consequently leads to an increase in the competitiveness of own enterprises - including those providing logistic services.

The use of the possibilities of quality engineering in logistics thus favors organizations in this area in reaching an organization conventionally referred to as the perfect organization [Kuc 2004].

\section{SELECTED APPLICATIONS OF QUALITY ENGINEERING IN LOGISTICS}


The possibilities of quality engineering previously presented are used successfully in the broadly understood logistics. Some selected examples in this field are briefly outlined below. These include road transport, production management and machine technology. In fact, they are in the area of supply chain management [Fechner 2007].

And so, first of all, selected works carried out in the field of road transport were briefly presented.

In the work [Świderski 2018] - interesting analyzes of activities supporting selected logistic operations have been made in relation to:

- public collective transport,

- general cargo transport,

- transport of food products,

- warehouse processes and inventory management, as well as receipt control of deliveries.

In relation to public road transport, where the research was passenger comfort, punctuality of courses, certainty of the planned journey, personal safety of passengers, etc., i.e. matters that are often a big problem for travelers, proving the imperfections of logistic operations in this area. As methods in the field of quality engineering diagnosing and improving the existing state of affairs, Pareto-Lorenz analysis, tree diagram and K. Ishikawa diagram [Świderski 2018].

As a result of the research carried out using quality engineering methods, the causes of existing imperfections were diagnosed, and actions affecting the improvement of the efficiency of logistic activities were carried out, as well as ways to prevent such errors.

The second of the discussed cases concerns road transport of general cargo, where various restrictions related to, among others, a significant problem with transport congestion, a ban on driving on weekends and holidays, at night, etc.

The above requires adapting to these restrictions by developing appropriate transport logistics plans - from supplier to recipient. Also in this case, one of the quality engineering methods, the FMEA method, has proved useful, as well as other methods of quality improvement in the distribution process [Świderski 2018]. Thanks to the above actions, it was possible to effectively fulfill orders placed by customers, which results in appropriate economic effects as well as customer confidence. It also positively translates into the image of a transport company. 
Another case of using quality engineering is its use in the transport of food products. As is known, the transport of food products of various groups, which is characterized by the specificity mainly associated with the fact that they are usually fast-moving and fast-rotating products. In addition, they must meet, among others requirements in terms of ensuring human and animal health and life. The above requires compliance with these restrictions, and thus compliance with relevant provisions in terms of food safety mainly in relation to means of transport.

To the above, there is a clear and clear marking of these products and packaging, ensuring that they are products as described - which is required by the relevant EU and national regulations [Korzeniowski, Skrzypek and Szyszka 2010]. Therefore, the logistics of this specific transport requires the preparation of a precise, comprehensive plan in the I/O system. Failure to meet these strict requirements, which is outlined in a nutshell - results in dangerous consequences for human and animal health.

Such a negative example is the experience of exporting domestic hard and soft fruit to the Scandinavian countries, where they appeared, including issues related to their improper packaging, stacking of full cardboard boxes on pallets, disregarding weather conditions in ports and at sea, failure to comply with the road card, as well as many other factors, resulting in significant damage and thus disqualification of transported goods [Hejduk et al. 2015].

To prevent these adverse events are used, among others quality engineering methods, such as brainstorming methods, engineering statistics methods, Pareto-Lorenz and K. Ishikawa diagrams, FMEA and QFD methods and others. The above limits the occurrence of occurring defects in the transport of food goods by road.

A further example is the use of quality engineering in storage processes. The main logistics activity in this area is transport, storage and distribution of goods with a number of accompanying activities. Hence, warehouse management must ensure proper customer service by delivering the right goods in line with Phola's theorem [Phol 2000].

In practice, this is a large area of activities related to the processes of: receiving goods, unloading, transporting goods to storage places, preparing appropriate warehouse documentation, and similar activities related to the release of transferred goods. The above requires control on each of the presented storage processes in terms of quality and quantity.

Helpful in the correct implementation of warehouse operations is the use of quality engineering methods, especially in cases of: damage to goods in the warehouse, damage to shipping units, improper protection of goods and their packaging, as well as inappropriate 130 
weather conditions, etc. In practice, quality supervision and improvement in the examples mentioned are secured it is usually quality engineering methods, such as - Pareto-Lorenz and K. Ishikawa, decision process diagrams, Bow-Tie method, as well as statistical analysis of the examined storage processes [Świderski 2018]. A practical example of such tests, in the case of frequently occurring damages during storage of stored goods, is the K.Ishikawa diagram.

Essential and very important issue in the area of logistics is the issue of inventory management, which generally boils down to activities related to inventory planning as well as control and regulation of their condition. The goal of inventory management is to minimize inventory costs while maintaining the desired level of service in the flow of goods. Hence, inventory management includes [Ślaski, 2017]:

- deciding on the range, size and time limit for placing orders for stock replenishment and

- tracking, measuring and correcting inventory levels depending on changing demand.

The above requires the creation and implementation of modern logistics technologies, increasingly functional IT systems supporting the flow of goods, services and information [Krzyżaniak 2008; Ślaski 2017].

The author of the work [Ślaski 2017] proposed to develop and implement a uniform, comprehensive methodology determining the process of designing and improving inventory management in logistics systems. Among the research methods used, he used optimization methods in the form of proprietary computer applications, including with the use of neural networks, methods of engineering statistics and economic methods guaranteeing an appropriate level of customer service with minimal inventory costs. Among the research methods used were, among others methods in the field of quality engineering or related to this discipline of science, and also applicable in production engineering such as kanban, MRP (Material Requirement Planning), DRP (Distribution Resource Planning) and others. The author of the cited work also drew attention to the need for integrated inventory management in logistics systems, which is also associated with the area of applied qualitology.

The above data also indicate the possibility of practical use of quality engineering methods in inventory management processes in logistics systems as well as recovery.

Each of the mentioned examples of applications of quality engineering methods is mostly supported by engineering statistics methods, especially in acceptance tests carried out in logistics, as in other areas of applied sciences, primarily production engineering and machine technology, as well as many others. 
Examples of such quality engineering applications are found in, for example, the hightechnology industry, such as aircraft construction, including helicopters. And so, the construction of an aircraft requires the development of a complex logistics supply chain of the elements necessary for production. Among many technological operations, the process of connecting aircraft fuselage sheets into a compact element is very important. The methods used for such joining are reduced to riveting or joining with fasteners - screws. It should be emphasized that these elements must meet the relevant requirements in terms of ownership as well as dimensions and be identifiable. The confusion of these elements is consequently one of the causes of aviation disasters.

Research on the methods of quality engineering of the logistics supply chain - Pareto - Lorenz methods and FMEA allowed to capture this problem on the technological line. As a result, an appropriate system has been developed to protect the technology - in this case helicopters, against such mistakes, Figure 3.

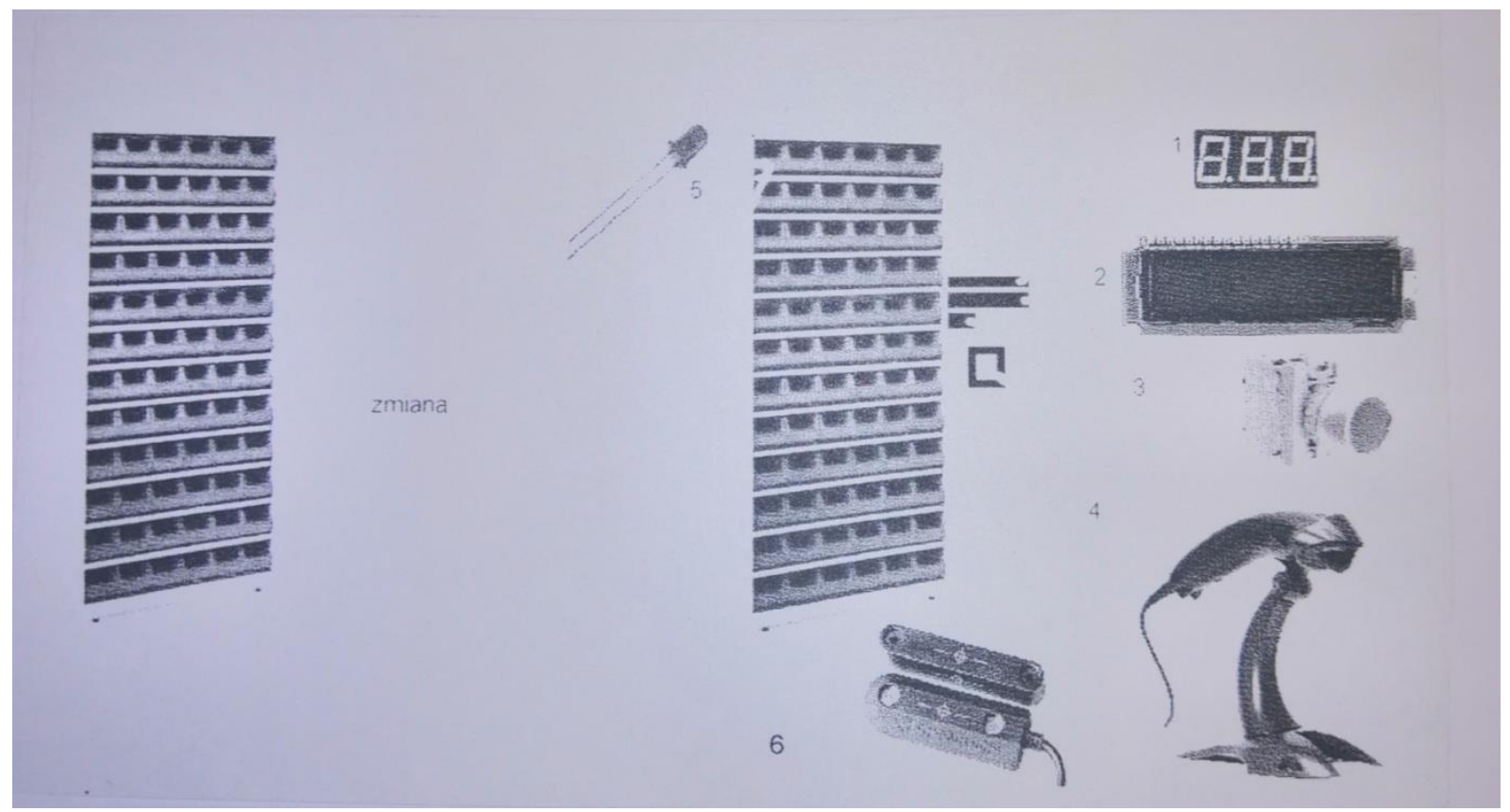

Fig. 3. A schematic diagram of the fastener collection for the production of helicopter hull (1 - LED display, 2 - LED display showing the scanned bar code from Job Card at the employee's disposal, 4 - code reader from Job Card, and 5 - data informing about pulling out the appropriate drawer with screws, 6 - drawer opening/extending sensors. Source: [Chochorowski 2019]

The above example once again confirms the usefulness of quality engineering methods in relation to implemented logistics processes.

\section{CONCLUSIVE REMARKS}


The chapter briefly presents the assumptions of quality engineering, its development possibilities, as well as selected examples of the application of this science discipline in logistics.

Selected examples are presented - including chains of activities in the field of road transport, in storage processes, inventory management, in high-technology industry and others.

It has been shown that the most commonly used applications of quality engineering methods presented in the chapter - originating from qualitology and other scientific disciplines, and widely used in logistics in the broad sense - are intended for the assessment of implemented logistics processes, removal of inconsistencies, as well as improvement of conducted activities. They also serve to improve the effectiveness of the analyzed logistics systems.

The applications of quality engineering research methods in logistics presented briefly - are therefore of great importance in practice, and also serve the development of cognitive work in this very important area of science.

It should be thought that the scope of application of these specific, interesting qualitonomic methods will find even wider application in most processes implemented in modern logistics.

\section{REFERENCES}

Blaik P., 2011, Logistyka, PWE, Warszawa.

Brzeziński M.,2015, Inżynieria systemów logistycznych, WAT, Warszawa.

Chochorowski M.J., 2019, Analiza systemu zarządzania jakością w przedsiębiorstwie przemysłu lotniczego, Politechnika Warszawska (Praca wykonana pod kierunkiem St. Tkaczyka).

Ćwiklicki M., Obora H., 2011, Hoshin Kanri, PWE, Warszawa.

Dudek M., 2002, Statystyczne metody sterowania jakością wybranych procesów technologicznych, Politechnika Śląska, Gliwice.

Fechner I., 2007, Zarządzanie łańcuchem dostaw, Wyższa Szkoła Logistyki, Poznań.

Hejduk A. i inni, 2011-2015, Packaging as a stimulus for economic growth of the region and improvement protection on the regional scale, Projekt PL0015 zrealizowany w ramach Norweskiego Mechanizmu Finansowego, SBŁ- COBRO - IBO, Warszawa.

Kolman R., 2009, Kwalitologia, Placet, Warszawa. 
Korzeniowski A., Skrzypek M., Szyszka G., 2010, Opakowania w systemach logistycznych, ILiM, Poznań.

Kowalska-Napora E., 2007, Model poprawy efektywności i jakości produkcji w przemyśle hutniczym w Polsce, Politechnika Śląska, Zabrze.

Krzyżaniak St., 2008, Podstawy zarządzania zapasami w przykładach, ILiM, Poznań.

Kuc R.B., 2004, Zarządzanie doskonałe, PTM, Warszawa.

Łunarski P., 2009, Zarządzanie jakością w logistyce, Oficyna Wydawnicza Politechniki Rzeszowskiej, Rzeszów.

Noga B., Noga M., 2019, Zarządzanie ryzykiem w procesie podejmowania decyzji ekonomicznych przez organizacje, CEDEWU, Warszawa.

Phol H.Ch., 2000, Logistik Systeme Betriebswirtschaftliche Grundlagen. Springer Verlag GmbH, Berlin.

Sałaciński T., 2017, Inżynieria Jakości w technikach wytwarzania, Oficyna Wydawnicza Politechniki Warszawskiej, Warszawa.

Szczepańska K., 2009,, Koszty jakości dla inżynierów, Placet, Warszawa.

Ślaski P., 2017, Zarządzanie zapasami w systemach logistycznych, Politechnika Warszawska, Warszawa.

Świderski A., 2018, Inżynieria jakości w wybranych obszarach transportu, ITS, Warszawa.

Tkaczyk St., 2000, Inżynieria jakości, a inżynieria materiałowa, IOiZwP ORGMASZ, Warszawa.

Tkaczyk St.(red.), 2010, Quality Management. Selected aspects, Elipsa, Warszawa.

Tkaczyk St., 2018, Zarządzanie w oparciu o kryterium jakości w wielowymiarowości zarządzania XXI wieku (red. Jakubiec M., Barcik A.), ATH, Bielsko-Biała. 